\title{
Strategie radzenia sobie ze stresem $w$ opinii pielęgniarek
}

\author{
Strategies for coping with stress in the opinion of nurses
}

\section{AGNIESZKA PIERNIKOWSKA', DOMINIKA PODSIADŁY²}

\author{
${ }^{1}$ Wojewódzki Szpital Specjalistyczny im. Bł. Ks. J. Popiełuszki we Włocławku \\ 2Oddział Pediatrii, Gastroenterologii, Kardiologii, Neurologii, Diabetologii \\ i Endokrynologii, Regionalny Szpital Specjalistyczny im. Dr. W. Biegańskiego w Grudziądzu
}

DOI: http://dx.doi.org/10.21784/IwP.2019.003

ISSN:2451-1846

\section{Streszczenie:}

Wstęp. W ogólnym ujęciu stres określany jest jako reakcja organizmu na stawiane psychiczne i fizyczne wymagania. Nieustanne narażanie się na stres zawodowy może doprowadzić do poważnych konsekwencji. Jedną z nich, szeroko opisywaną w literaturze, jest zespół wypalenia zawodowego pielęgniarek. Aktualne koncepcje radzenia sobie ze stresem określają osobowościowe oznaki odporności na stres jako „mediatorami procesu stresowego".

Cel. Celem przeprowadzonych badań jest analiza opinii pielęgniarek na temat strategii radzenia sobie ze stresem.

Materiał i metody. Badaniami objęto grupę 70 pielęgniarek i pielęgniarzy pracujących na oddziałach zachowawczych i zabiegowych w Regionalnym Szpitalu Specjalistycznym im. dr W. Biegańskiego w Grudziądzu, po uzyskaniu pozytywnej zgody Komisji Bioetycznej Uniwersytetu Mikołaja Kopernika w Toruniu przy Collegium Medicum im. Ludwika Rydygiera w Bydgoszczy oraz zgody Dyrekcji szpitala. Wykorzystano metodę sondażu diagnostycznego, technikę ankietowania oraz autorski kwestionariusz ankiety i standaryzowany kwestionariusz Mini-Cope. 
Wyniki. W wyniku przeprowadzonych badań stwierdzono, iż pielęgniarki z najmłodszej kategorii wiekowej i z najkrótszym stażem pracy istotnie częściej wybierały strategie: pozytywne przewartościowanie, poczucie humoru oraz zajmowanie się czymś innym. Jako strategię radzenia sobie ze stresem w postaci poszukiwania wsparcia instrumentalnego częściej wybierały pielęgniarki w grupie 36-45 lat. Natomiast absolwenci z wyższym wykształceniem stawiali na aktywne radzenie sobie, zajmowanie się czymś innym, pozytywne przewartościowanie i rozwój. $\mathrm{Z}$ kolei niższe wykształcenie wskazywało na aktywne radzenie sobie, planowanie i zajmowanie się czymś innym.

Wnioski. Według opinii respondentów praca pielęgniarki/pielęgniarza jest często stresująca. Stosowanymi strategiami radzenia sobie ze stresem jest aktywne radzenie sobie, planowanie, zajmowanie się czymś innym. Średni wiek badanych pielęgniarek/pielęgniarzy wyniósł 43 lata. Najliczniejszą grupę stanowili badani $\mathrm{z}$ ukończonym liceum medycznym $(41,4 \%)$, natomiast najmniejszą studium medyczne $(8,6 \%)$.

Słowa kluczowe: strategia, stres, pielęgniarka

\begin{abstract}
:
Introduction. In general, stress is defined as the body's response to the psychological and physical demands. The constant exposure to professional stress can lead to serious consequences. One of them, widely described in the literature, is the burnout syndrome of nurses. Current concepts of coping with stress determine the personality signs of resistance to stress as "mediators of the stress process"

Aim. The aim of the conducted research is to analyze the nurses' opinions on the strategy of coping with stress.

Materials and methods. The study involved a group of 70 nurses working on conservative and surgical wards in the Regional Specialist Hospital Dr W. Biegański in Grudziądz, after obtaining the positive consent of the Bioethical Commission of the Nicolaus Copernicus University in Torun at Collegium Medicum Ludwika Rydygiera in Bydgoszcz and the consent of the Hospital Management. The method of diagnostics survey, questionnaire technique and author's questionnaire and standardized MiniCope questionnaire were used.
\end{abstract}


Results.As a result of the conducted research, it was found that nurses from the youngest group and with the shortest seniority significantly more often chose the following strategies: positive re-evaluation, sense of humor and other activities. Nurses in the 36-45 age group were more likely to choose to seek instrumental support as a strategy of coping with stress. However, graduates with higher education focused on active coping activities , positive reevaluation and development as well as other activities. In turn, lower education indicated active coping activities, planning and other activities.

Conclusions. According to the respondents, the nurse job is often stressful. The strategies used to cope with stress are active coping activities, planning, and other activities. The average age of the examined nurses was 43 years. The largest group involved the respondents with medical school education (41.4\%), while the smallest medical higher education (8.6\%).

Keywords: strategy, stress, nurse

\section{Wstęp}

W ogólnym ujęciu stres określany jest jako reakcja organizmu na stawiane psychiczne i fizyczne wymagania. Reakcje te mogą mieć charakter psychologiczny bądź biologiczny, jednak często występują razem jako psychospołeczna całość. Stres możemy podzielić na dwa rodzaje: biologiczny i psychologiczny [1].

Nawiązując do definicji stresu, należy również wspomnieć o specyficznym rodzaju stresu jakim jest stres zawodowy. Jest to relacja jaka zachodzi pomiędzy miejscem pracy, a pracownikiem; składają się na jej przebieg warunki społeczne jak i fizyczne. Aspekt społeczny dotyczy atmosfery panującej w pracy, planowania jej zakresu czy też wynagrodzenia oferowanego przez pracodawcę. Z kolei warunki fizyczne odnoszą się do natężenia hałasu, temperatury czy wyposażenia stanowiska [2].

Nieustanne narażanie się na stres zawodowy może doprowadzić do poważnych konsekwencji. Jedną z nich, szeroko opisywaną w literaturze, jest zespół wypalenia zawodowego 
pielęgniarek. Duża odpowiedzialność za zdrowie i życie człowieka, kontakt ze śmiercią, a przy tym niewystarczające uposażenie i przeciążenie pracą odciskają swoje piętno zwłaszcza na starszych zarówno wiekiem, jak i stażem pracy, pielęgniarkach.

Zespół wypalenia zawodowego jest więc „dysfunkcjonalnym stanem, który jest skutkiem chronicznej ekspozycji na stres" $[3,4,5]$. Główną przyczynę wypalenia zawodowego upatruje się przede wszystkim w długotrwałym chronicznym stresie. Jednak cechy osobowości i środowisko zewnętrzne ma również wpływ na syndromu „burn out” [6,7].

Pojęcie „radzenia sobie ze stresem” stanowi element składowej tzw. „sytuacji stresowej. Po raz pierwszy pojęcie to zostało wprowadzone $\mathrm{w}$ latach $60 \mathrm{XX}$ wieku. Strategia radzenia sobie ze stresem stanowi element procesu radzenia sobie, oznacza stale zmieniający się sposób podejmowania decyzji i działania w reakcji na sytuację stresującą [8].

Aktualne koncepcje radzenia sobie ze stresem określają osobowościowe oznaki odporności na stres jako „mediatorami procesu stresowego". Główne to wsparcie społeczne oraz zasoby osobowościowe [6,9].

Według R. Lazarusa i S. Folkmana strategie radzenia sobie ze stresem to "stale zmieniające się poznawcze i behawioralne wysiłki, mające na celu opanowanie określonych zewnętrznych i wewnętrznych wymagań, ocenianych przez osobę jako obciążające lub przekraczające jego zasoby" [10].

Opierając się na transakcyjnej teorii stresu N.S. Endler i J.D.A. Parker wyróżnili następujące style radzenia sobie ze stresem:

- Styl skoncentrowany na zadaniu - opiera się na kontroli źródła stresu, szukaniu twórczych rozwiązań oraz wsparciu.

- Styl skoncentrowany na emocjach - dotyczy zmniejszenia napięcia emocjonalnego, do jakiego dochodzi w skutek działania bodźców stresowych. 
- Styl skoncentrowany na unikaniu - zawiera zredukowanie niepożądanych działań stresorów, polega na „unikaniu”, odwróceniu uwagi od sytuacji stresującej [7].

Celem pracy jest analiza opinii pielęgniarek na temat strategii radzenia sobie ze stresem. Ocena dokonana została na podstawie wybranych danych socjodemograficznych.

\section{Materiał i metody}

Badaniami objęto grupę 70 pielęgniarek i pielęgniarzy pracujących na oddziałach zachowawczych i zabiegowych w Regionalnym Szpitalu Specjalistycznym im. dr W. Biegańskiego w Grudziądzu. Procedura badawcza realizowana była po uzyskaniu pozytywnej opinii Komisji Bioetycznej Uniwersytetu Mikołaja Kopernika w Toruniu; Collegium Medicum im L. Rydygiera w Bydgoszczy oraz zgody Dyrekcji Szpitala.

Badania miały charakter anonimowy, dobrowolny, bezpłatny. Metodą badań był sondaż diagnostyczny natomiast techniką ankietowanie. W powyższych badaniach użyto kwestionariusza ankiety własnej oraz kwestionariusza standaryzowanego - MiniCope.

Wszystkie uzyskane wyniki wprowadzono do bazy danych programu Statistica 10.0, a następnie poddano analizie statystycznej, stosując statystykę opisową, oraz z wykorzystaniem testów istotności statystycznej.

\section{Wyniki}

Tabela 1. Średnie wieku badanych. 


\begin{tabular}{|c|c|c|c|c|c|c|c|c|c|c|}
\hline $\begin{array}{c}\text { Zmienn } \\
\text { a }\end{array}$ & $\mathbf{N}$ & $\begin{array}{c}\text { Średni } \\
\mathbf{a}\end{array}$ & $\mathbf{S D}$ & $\begin{array}{c}\text { Ufnoś } \\
\mathbf{c} \\
\mathbf{9 5 , 0} \\
\mathbf{\%}\end{array}$ & $\begin{array}{c}\text { Ufność } \\
\mathbf{+ 9 5 , 0} \\
\mathbf{9}\end{array}$ & $\begin{array}{c}\mathbf{m i} \\
\mathbf{n}\end{array}$ & $\begin{array}{c}\text { Ma } \\
\mathbf{x}\end{array}$ & $\begin{array}{c}\mathbf{Q 2} \\
\mathbf{5}\end{array}$ & $\begin{array}{c}\text { median } \\
\mathbf{a}\end{array}$ & $\begin{array}{c}\mathbf{Q 7} \\
\mathbf{5}\end{array}$ \\
\hline $\begin{array}{c}\text { Wiek } \\
\text { badanyc } \\
\text { h }\end{array}$ & 7 & 43,0 & $\begin{array}{c}10,44 \\
4\end{array}$ & 40,55 & 45,53 & $\begin{array}{c}22, \\
0\end{array}$ & $\begin{array}{c}59, \\
0\end{array}$ & $\begin{array}{c}39, \\
0\end{array}$ & 45,5 & $\begin{array}{c}50 \\
0\end{array}$ \\
\hline
\end{tabular}

Źródło: wynik badań własnych

Średnia wieku badanych wyniosła 43 lata. Odchylenie standardowe stanowiło $24,3 \%$ wartości średniej, co świadczy o przeciętnym zróżnicowaniu wieku.

Tabela 2. Wykształcenie badanych.

\begin{tabular}{|c|c|c|}
\hline wykształcenie & N & \% \\
\hline liceum medyczne & 29 & 41,4 \\
\hline studium medyczne & 6 & 8,6 \\
\hline licencjat pielęgniarstwa & 19 & 27,1 \\
\hline $\begin{array}{c}\text { magister } \\
\text { pielęgniarstwa }\end{array}$ & 16 & 22,9 \\
\hline razem & 70 & 100,0 \\
\hline
\end{tabular}

Źródło: wynik badań własnych

Najbardziej liczną grupę stanowili badani, którzy ukończyli liceum medyczne - 29 osób (41,4\%), najmniej liczną grupę z kolei studium medyczne - 6 osób $(8,6 \%)$.

Tabela 3. Częstość występowania stresu $w$ pracy pielęgniarki/pielęgniarza. 


\begin{tabular}{|c|c|c|}
\hline Oddział & \multicolumn{2}{|c|}{ Razem } \\
\hline Odpowiedź & n & \% \\
\hline Często & 52 & 74,3 \\
\hline Czasami & 18 & 25,7 \\
\hline Nigdy & 0 & 0,0 \\
\hline Razem & 70 & 100,0 \\
\hline
\end{tabular}

Źródło: wynik badań własnych

Najwięcej badanych odpowiedziało, że praca pielęgniarki/ pielęgniarza jest często stresująca - 52 osoby (74,3\%). Nikt $\mathrm{z}$ badanych nie wskazał że jego praca nigdy go nie stresuje.

Rycina 2. Średnie wyniki strategii radzenia sobie ze stresem.

\begin{tabular}{|c|c|c|c|c|c|c|c|c|c|}
\hline Lp & Strategia & $\mathbf{N}$ & $\begin{array}{c}\text { Śre } \\
\mathbf{d n i} \\
\mathbf{a}\end{array}$ & $\mathbf{S D}$ & $\begin{array}{c}\text { Ufność } \\
\mathbf{-}\end{array}$ & $\begin{array}{c}\text { Ufność } \\
\mathbf{+ 9 5 , 0 \%}\end{array}$ & mediana & Min & Max \\
\hline 1 & $\begin{array}{c}\text { aktywne radzenie } \\
\text { sobie }\end{array}$ & 70 & 2,00 & 0,631 & 1,85 & 2,15 & 2,0 & 0,0 & 3,0 \\
\hline 2 & \begin{tabular}{c} 
Planowanie \\
\hline 3
\end{tabular} & 70 & 1,84 & 0,581 & 1,70 & 1,98 & 2,0 & 0,5 & 3,0 \\
\hline $\begin{array}{c}\text { przewytywne } \\
\text { nie }\end{array}$ & 70 & 1,73 & 0,630 & 1,58 & 1,88 & 2,0 & 0,0 & 3,0 \\
\hline 4 & $\begin{array}{c}\text { Akceptacja } \\
5\end{array}$ & 70 & 1,69 & 0,683 & 1,53 & 1,86 & 2,0 & 0,0 & 3,0 \\
\hline
\end{tabular}




\begin{tabular}{|c|c|c|c|c|c|c|c|c|c|}
\hline 6 & zwrot ku religii & 70 & 0,82 & 0,897 & 0,61 & 1,04 & 0,5 & 0,0 & 3,0 \\
\hline 7 & $\begin{array}{c}\text { poszukiwanie } \\
\text { wsparcia } \\
\text { emocjonalnego }\end{array}$ & 70 & 1,77 & 0,769 & 1,59 & 1,95 & 2,0 & 0,0 & 3,0 \\
\hline 8 & $\begin{array}{c}\text { poszukiwanie } \\
\text { wsparcia } \\
\text { instrumentalnego }\end{array}$ & 70 & 1,51 & 0,730 & 1,33 & 1,68 & 1,5 & 0,0 & 3,0 \\
\hline 9 & $\begin{array}{c}\text { zajmowanie się } \\
\text { czymś innym }\end{array}$ & 70 & 1,82 & 0,626 & 1,67 & 1,97 & 2,0 & 0,0 & 3,0 \\
\hline 10 & Zaprzeczanie & 70 & 0,71 & 0,611 & 0,56 & 0,85 & 0,5 & 0,0 & 2,0 \\
\hline 11 & wyładowanie & 70 & 1,24 & 0,706 & 1,07 & 1,41 & 1,5 & 0,0 & 2,5 \\
\hline
\end{tabular}

Źródło: wynik badań własnych

Najczęściej stosowane przez badanych strategie radzenia sobie ze stresem to przede wszystkim aktywne radzenie sobie średnia 2,0 punkty, dalej planowanie - średnia 1,84 punktu, zajmowanie się czymś innym - średnia 1,82 punktu, poszukiwanie wsparcia emocjonalnego - średnia 1,77 punktu oraz pozytywne przewartościowanie i rozwój - średnia 1,73 punktu.

W najmniejszym stopniu respondenci stosowali takie strategie jak: zwrot ku religii - średnia 0,82 punktu, poczucie humoru - średnia 0,73 punktu, zaprzeczanie - średnia 0,71 punktu, zaprzestanie działań - średnia 0,64 punktu oraz zażywanie substancji psychoaktywnych - średnia 0,26 punktu.

Tabela 4. Średnie wyniki strategii radzenia sobie ze stresem w zależności od wieku badanych. 


\begin{tabular}{|c|c|c|c|c|c|c|c|c|}
\hline \multirow{2}{*}{$\begin{array}{c}\text { grupa wiekowa } \\
\text { Strategia }\end{array}$} & \multicolumn{2}{|c|}{$22-35$ lat } & \multicolumn{2}{|c|}{$36-45$ lat } & \multicolumn{2}{|c|}{ 46-50 lat } & \multicolumn{2}{|c|}{$\begin{array}{c}\text { powyżej } 50 \\
\text { lat }\end{array}$} \\
\hline & średnia & SD & średnia & SD & średnia & SD & średnia & SD \\
\hline $\begin{array}{c}\text { aktywne radzenie } \\
\text { sobie }\end{array}$ & 1,94 & 0,73 & 2,08 & 0,52 & 1,97 & 0,61 & 2,00 & 0,71 \\
\hline planowanie & 1,85 & 0,75 & 1,89 & 0,47 & 1,87 & 0,52 & 1,75 & 0,61 \\
\hline $\begin{array}{c}\text { pozytywne } \\
\text { przewartościowanie }\end{array}$ & 2,00 & 0,61 & 1,81 & 0,42 & 1,61 & 0,68 & 1,50 & 0,71 \\
\hline akceptacja & 1,97 & 0,91 & 1,72 & 0,46 & 1,45 & 0,64 & 1,66 & 0,60 \\
\hline poczucie humoru & 0,91 & 0,51 & 0,86 & 0,66 & 0,53 & 0,39 & 0,63 & 0,70 \\
\hline zwrot ku religii & 0,76 & 0,90 & 1,06 & 1,17 & 0,58 & 0,51 & 0,91 & 0,90 \\
\hline $\begin{array}{l}\text { szukanie wsparcia } \\
\text { emocjonalnego }\end{array}$ & 1,76 & 0,92 & 1,89 & 0,72 & 1,92 & 0,84 & 1,47 & 0,50 \\
\hline $\begin{array}{l}\text { szukanie wsparcia } \\
\text { instrumentalnego }\end{array}$ & 1,65 & 0,79 & 1,72 & 0,67 & 1,42 & 0,80 & 1,22 & 0,58 \\
\hline $\begin{array}{c}\text { zajęcie się czymśs } \\
\text { innym }\end{array}$ & 2,03 & 0,72 & 1,92 & 0,62 & 1,68 & 0,61 & 1,66 & 0,51 \\
\hline Zaprzeczanie & 0,50 & 0,59 & 0,94 & 0,64 & 0,74 & 0,65 & 0,63 & 0,50 \\
\hline wyładowanie & 1,35 & 0,68 & 1,28 & 0,67 & 1,21 & 0,80 & 1,13 & 0,70 \\
\hline $\begin{array}{c}\text { zażywanie } \\
\text { substancji } \\
\text { psychoaktywnych }\end{array}$ & 0,29 & 0,59 & 0,44 & 0,57 & 0,13 & 0,33 & 0,16 & 0,35 \\
\hline $\begin{array}{c}\text { zaprzestanie } \\
\text { działań }\end{array}$ & 0,59 & 0,64 & 0,72 & 0,60 & 0,58 & 0,61 & 0,69 & 0,57 \\
\hline obwinianie siebie & 1,18 & 0,79 & 1,03 & 0,65 & 0,97 & 0,74 & 1,28 & 0,66 \\
\hline
\end{tabular}

Źródło: wynik badań własnych

Respondenci w wieku 22-35 lat w radzeniu sobie ze stresem stosowali najczęściej takie strategie jak: zajmowanie się czymś innym 
- 2,03 punktu, pozytywne przewartościowanie i rozwój - 2,0 punkty, akceptacja - 1,97 punktu oraz aktywne radzenie sobie - 1,94 punktu. W najmniejszym stopniu: zwrot ku religii - 0,76 punktu, zaprzestanie działań - 0,59 punktu, zaprzeczanie - 0,5 punktu oraz zażywanie substancji psychoaktywnych - 0,29 punktu.

Z kolei badani średniej grupy wiekowej 36-45 lat w radzeniu sobie ze stresem stosowali najczęściej takie strategie jak: aktywne radzenie sobie - 2,08 punktu, zajmowanie się czymś innym - 1,92 punktu, planowanie - 1,89 punktu oraz poszukiwanie wsparcia emocjonalnego - 1,89 punktu. W najmniejszym stopniu: zaprzeczanie - 0,94 punktu, poczucie humoru - 0,86 punktu, zaprzestanie działań 0,72 punktu oraz zażywanie substancji psychoaktywnych - 0,44 punktu.

Respondenci między 46 a 50 rokiem życia w radzeniu sobie ze stresem stosowali najczęściej takie strategie jak: aktywne radzenie sobie - 1,97 punktu, poszukiwanie wsparcia emocjonalnego - 1,92 punktu, planowanie - 1,87 punktu oraz zajmowanie się czymś innym - 1,68 punktu. W mniejszym stopniu osoby te wybierały strategie zwrot ku religii - 0,58 punktu oraz zaprzestanie działań 0,58 punktu oraz poczucie humoru - 0,53 punktu . Zażywanie substancji psychoaktywnych było najrzadziej wybieraną strategią 0,13 punktu

Najstarsi ankietowani powyżej 50 lat w radzeniu sobie ze stresem preferowali takie strategie jak: aktywne radzenie sobie - 2,0 punkty, planowanie - 1,75 punktu, zajmowanie się czymś innym 1,66 punktu oraz akceptacja - 1,66 punktu. W najmniejszym stopniu: zaprzestanie działań - 0,69 punktu, zaprzeczanie - 0,63 punktu, poczucie humoru - 0,63 punktu oraz zażywanie substancji psychoaktywnych - 0,16 punktu.

Tabela 5. Średnie wyniki strategii radzenia sobie ze stresem w zależności od wykształcenia badanych. 


\begin{tabular}{|c|c|c|c|c|c|c|c|c|}
\hline \multirow{2}{*}{$\begin{array}{c}\text { Wykształcenie } \\
\text { Strategia }\end{array}$} & \multicolumn{2}{|c|}{$\begin{array}{c}\text { liceum } \\
\text { medyczne }\end{array}$} & \multicolumn{2}{|c|}{$\begin{array}{l}\text { studium } \\
\text { medyczne }\end{array}$} & \multicolumn{2}{|c|}{$\begin{array}{c}\text { licencjat } \\
\text { pielęgniarstw } \\
\text { a }\end{array}$} & \multicolumn{2}{|c|}{$\begin{array}{c}\text { magister } \\
\text { pielęgniarstw } \\
\text { a }\end{array}$} \\
\hline & $\begin{array}{l}\text { średni } \\
\text { a }\end{array}$ & SD & $\begin{array}{c}\text { średni } \\
\text { a }\end{array}$ & SD & średnia & SD & średnia & SD \\
\hline $\begin{array}{c}\text { aktywne radzenie } \\
\text { sobie }\end{array}$ & 1,91 & $\begin{array}{c}0,6 \\
8\end{array}$ & 2,08 & $\begin{array}{c}0,3 \\
8\end{array}$ & 2,03 & $\begin{array}{c}0,3 \\
9\end{array}$ & 2,09 & 0,84 \\
\hline planowanie & 1,86 & $\begin{array}{c}0,4 \\
6\end{array}$ & 1,08 & $\begin{array}{c}0,5 \\
8\end{array}$ & 1,97 & $\begin{array}{c}0,5 \\
1\end{array}$ & 1,94 & 0,68 \\
\hline $\begin{array}{c}\text { pozytywne } \\
\text { przewartościowani } \\
\text { e }\end{array}$ & 1,67 & $\begin{array}{c}0,5 \\
7\end{array}$ & 1,17 & $\begin{array}{c}0,8 \\
2\end{array}$ & 1,79 & $\begin{array}{c}0,6 \\
5\end{array}$ & 1,97 & 0,53 \\
\hline akceptacja & 1,60 & $\begin{array}{c}0,6 \\
2\end{array}$ & 1,50 & $\begin{array}{c}0,7 \\
1\end{array}$ & 1,74 & $\begin{array}{c}0,8 \\
6\end{array}$ & 1,88 & 0,56 \\
\hline poczucie humoru & 0,60 & $\begin{array}{c}0,5 \\
4\end{array}$ & 0,67 & $\begin{array}{c}0,7 \\
5\end{array}$ & 0,71 & $\begin{array}{c}0,4 \\
5\end{array}$ & 1,00 & 0,68 \\
\hline zwrot ku religii & 0,91 & $\begin{array}{c}0,8 \\
6\end{array}$ & 0,25 & $\begin{array}{c}0,4 \\
2\end{array}$ & 0,76 & $\begin{array}{c}1,0 \\
1\end{array}$ & 0,94 & 0,95 \\
\hline $\begin{array}{l}\text { szukanie wsparcia } \\
\text { emocjonalnego }\end{array}$ & 1,83 & $\begin{array}{c}0,6 \\
6\end{array}$ & 1,25 & $\begin{array}{c}0,6 \\
9\end{array}$ & 1,95 & $\begin{array}{c}0,8 \\
1\end{array}$ & 1,66 & 0,89 \\
\hline $\begin{array}{l}\text { szukanie wsparcia } \\
\text { instrumentalnego }\end{array}$ & 1,45 & $\begin{array}{c}0,6 \\
6\end{array}$ & 1,00 & $\begin{array}{c}0,7 \\
1\end{array}$ & 1,76 & $\begin{array}{c}0,7 \\
5\end{array}$ & 1,50 & 0,77 \\
\hline $\begin{array}{l}\text { zajmowanie się } \\
\text { czymś innym }\end{array}$ & 1,59 & $\begin{array}{c}0,5 \\
2\end{array}$ & 1,83 & $\begin{array}{c}0,6 \\
8\end{array}$ & 2,21 & $\begin{array}{c}0,4 \\
5\end{array}$ & 1,78 & 0,77 \\
\hline Zaprzeczanie & 0,59 & $\begin{array}{c}0,5 \\
5\end{array}$ & 0,83 & $\begin{array}{c}0,6 \\
8\end{array}$ & 0,92 & $\begin{array}{c}0,6 \\
5\end{array}$ & 0,63 & 0,62 \\
\hline wyładowanie & 1,24 & $\begin{array}{c}0,6 \\
9\end{array}$ & 1,00 & $\begin{array}{c}0,7 \\
1\end{array}$ & 1,32 & $\begin{array}{c}0,7 \\
9\end{array}$ & 1,25 & 0,68 \\
\hline $\begin{array}{c}\text { zażywanie } \\
\text { substancji } \\
\text { psychoaktywnych }\end{array}$ & 0,21 & $\begin{array}{c}0,3 \\
9\end{array}$ & 0,00 & $\begin{array}{c}0,0 \\
0\end{array}$ & 0,42 & $\begin{array}{c}0,5 \\
8\end{array}$ & 0,25 & 0,55 \\
\hline $\begin{array}{l}\text { zaprzestanie } \\
\text { działań }\end{array}$ & 0,48 & $\begin{array}{c}0,5 \\
4\end{array}$ & 1,00 & $\begin{array}{c}0,5 \\
5\end{array}$ & 0,84 & $\begin{array}{c}0,6 \\
9\end{array}$ & 0,56 & 0,51 \\
\hline obwinianie siebie & 1,16 & $\begin{array}{c}0,7 \\
1\end{array}$ & 0,58 & $\begin{array}{c}0,5 \\
8\end{array}$ & 1,47 & $\begin{array}{c}0,5 \\
9\end{array}$ & 0,78 & 0,66 \\
\hline
\end{tabular}

Źródło: wynik badań własnych 
Badani, którzy byli absolwentami, stosowali najczęściej takie strategie radzenia sobie ze stresem jak: aktywne radzenie sobie 1,91 punktu, planowanie - 1,86 punktu, poszukiwanie wsparcia emocjonalnego - 1,83 punktu oraz pozytywne przewartościowanie i rozwój - 1,67 punktu. W najmniejszym stopniu z kolei wybierali takie strategie jak: poczucie humoru - 0,6 punktu, zaprzeczanie 0,59 punktu, zaprzestanie działań - 0,48 punktu, oraz zażywanie substancji psychoaktywnych - 0,21 punktu.

Badani, którzy ukończyli studium medycznym, stosowali najczęściej takie strategie radzenia sobie ze stresem jak: aktywne radzenie sobie - 2,08 punktu, zajmowanie się czymś innym 1,83 punktu, akceptacja - 1,5 punktu oraz poszukiwanie wsparcia emocjonalnego - 1,25 punktu. W najmniejszym stopniu $\mathrm{z}$ kolei wybierali strategie takie jak: poczucie humoru - 0,67 punktu, obwinianie siebie $-0,58$ punktu, zwrot ku religii $-0,25$ punktu oraz nie stosowano $w$ ogóle strategii zażywanie substancji psychoaktywnych - 0,0 punktów.

Badani z licencjatem pielęgniarstwa preferowali strategie w największym stopniu takie strategie radzenia sobie ze stresem jak: zajmowanie się czymś innym - 2,21 punktu, aktywne radzenie sobie 2,03 punktu, planowanie - 1,97 punktu oraz poszukiwanie wsparcia emocjonalnego - 1,95 punktu. Najmniej z kolei wybierali strategie: zaprzestanie działań - 0,84 punktu, zwrot ku religii - 0,76 punktu, poczucie humoru - 0,71 punktu oraz zażywanie substancji psychoaktywnych - 0,42 punktu.

Ankietowani, którzy uzyskali tytuł magistra pielęgniarstwa, najczęściej stosowali 4 strategie: aktywne radzenie sobie - 2,09 punktu, pozytywne przewartościowanie i rozwój - 1,97 punktu, planowanie - 1,94 punktu oraz akceptacja - 1,88 punktu. $\mathrm{W}$ najmniejszym stopniu $\mathrm{z}$ kolei wybierali strategie takie jak: obwinianie siebie - 0,78 punktu, zaprzeczanie - 0,63 punktu, zaprzestanie działań - 0,56 punktu oraz zażywanie substancji psychoaktywnych - 0,25 punktu. 


\section{Dyskusja}

Praca należy do najważniejszych form aktywności człowieka. Mianem definicji pracy określa się wykonywanie czynności zarobkowej i zawodowej, która służy do realizowania wartości użytkowych, kulturowych czy materialnych [11]. Dzięki pracy człowiek może zaspokajać potrzebę przynależności, dawać poczucie bezpieczeństwa najbliższym. Praca zawodowa może uczyć nowych umiejętności oraz radzenia sobie z nowymi wyzwaniami. W pracy możemy także nawiązywać przyjaźnie, poznawać ludzi o różnych zainteresowaniach. Jednakże nie zawsze może być ona źródłem satysfakcji; często zdarza się że, stanowi powód niezadowolenia czy frustracji [12].

Wszyscy ankietowani $\mathrm{w}$ badaniach własnych uznali pracę pielęgniarki za stresującą, a ponad $90 \%$ uznało, że stres występuje często w pracy zawodowej.

Literatura także przedstawia na podstawie przeprowadzonych badań, że znaczny odsetek środowiska pielęgniarskiego podaje, ę praca zawodowa ma czynnik stresogenny. Potwierdzają ten fakt między innymi badania Kowalczuk i wsp. [13], w których ponad 70\% ankietowanych pielęgniarek było narażonych na stres. Także wyniki podane w badaniach Modzelewskiej i Kulik [14] przedstawiają podobny odsetek występowania stresu w pracy pielęgniarki/pielęgniarza. Wykazano bowiem, że blisko trzy czwarte respondentów pielęgniarek $\mathrm{z}$ Lublina odczuwało stres związany z wykonywaną pracą. Autorzy Pietraszek i wsp. [15] badali 278 pielęgniarek z Lublina i Krosna. Ponad 95\% pielęgniarek podało, że ich zawód jest stresujący, a ponad połowa deklarowała, że sytuacje stresujące mają miejsce w ich pracy zawodowej codziennie [16].

W aktualnych badaniach znacząca większość badanych deklarowała, że próbuje radzić sobie ze stresem w pracy zawodowej. Najczęściej stosowanymi strategiami radzenia sobie ze stresem były 
aktywne radzenie sobie, planowanie oraz zajmowanie się czymś innym. Najmniej popularne strategie to z kolei: zażywanie substancji psychoaktywnych, zaprzestanie działań i zaprzeczanie.

Wiek badanych różnicował istotnie statystycznie stosowanie przez nich kilku strategii radzenia sobie ze stresem. Pozostawał jednak $\mathrm{w}$ słabej korelacji $\mathrm{z}$ takimi strategiami jak: pozytywne przewartościowanie, poczucie humoru, poszukiwanie wsparcia instrumentalnego i zajmowanie się czymś innym. Respondenci w wieku 22-35 lat stosowali najczęściej strategie: zajmowanie się czymś innym - 2,03 punktu, pozytywne przewartościowanie i rozwój - 2,0 punkty. Z kolei badani między 36-45 rokiem życia wybierali najczęściej strategie: aktywne radzenie sobie - 2,08 punktu, zajmowanie się czymś innym - 1,92 punktu. Badani w wieku 46-50 lat stosowali najczęściej strategie: aktywne radzenie sobie - 1,97 punktu, poszukiwanie wsparcia emocjonalnego - 1,92 punktu. Najstarsi respondenci powyżej 50 lat jako najczęściej wybieraną strategię wskazali aktywne radzenie sobie $-2,0$ punkty oraz planowanie $-1,75$ punktu.

Wykształcenie badanych, pozostawało w istotnej statystycznie, niskiej korelacji z takimi wynikami stosowania strategii radzenia sobie ze stresem jak: poczucie humoru oraz zajmowanie się czymś innym. Absolwenci liceum medycznego stosowali najczęściej strategie: aktywne radzenie sobie - 1,91 punktu, planowanie - 1,86 punktu. Respondenci, którzy ukończyli studium medycznym wybierali strategie: aktywne radzenie sobie - 2,08 punktu oraz zajmowanie się czymś innym - 1,83 punktu. Badani, którzy posiadali tytuł licencjata pielęgniarstwa, stosowali najczęściej strategie: zajmowanie się czymś innym - 2,21 punktu, aktywne radzenie sobie 2,03 punktu. Badani posiadający tytuł magistra pielęgniarstwa, najczęściej wybierali strategie: aktywne radzenie sobie - 2,09 punktu, pozytywne przewartościowanie i rozwój - 1,97 punktu.

Śniegocka M. w swoich badaniach wykazała korelację między strategią radzenia sobie ze stresem a wiekiem i wykształceniem 
respondentów. Pielęgniarki, które posiadały wyższe wykształcenie częściej stosowały strategie aktywnego radzenie sobie oraz strategie planowania. W badaniach przeprowadzonych przez Śniegocką ukazano, że wiek ma wpływ na częstość stosowania strategii: „poczucie humoru” oraz „unikanie działań konkurencyjnych”. Respondenci poniżej 40 roku życia częściej skłaniali się ku stylom, które koncentrowały się na problemie oraz zachowaniach unikowych. Po 40 roku życia wzrasta tendencja do stosowania strategii radzenia sobie „zwrot ku religii”, co może wynikać z potrzeby wsparcia emocjonalnego [17].

\title{
Wnioski
}

Przeprowadzone badanie pozwoliły na sformułowanie następujących wniosków:

1. Według opinii respondentów praca pielęgniarki/pielęgniarza jest często stresująca.

2. Stosowanymi strategiami radzenia sobie ze stresem jest aktywne radzenie sobie, planowanie, zajmowanie się czymś innym.

3. Średnia wieku badanych pielęgniarek/pielęgniarzy wyniosła 43 lata

4. W zależności od wykształcenia respondentów radzenie sobie ze stresem odbywa się w wieloraki sposób: od aktywnego radzenia sobie, pozytywnego przewartościowania i rozwoju (w przypadku wyższego wykształcenia), po planowanie, bądź zajmowanie się czymś innym (w przypadku wykształcenia średniego).

\section{Zalecenia dla praktyki pielęgniarskiej}

\author{
Przeprowadzone badania w bardzo dogłębny sposób \\ przedstawiają problem stresu $\mathrm{w}$ środowisku pielęgniarek.
}


Udowodniono, iż wiek badanych pielęgniarek/pielęgniarzy pozostawał w całkowitej współzależności ze stosowaniem strategii, polegającej na pozytywnym przewartościowaniu, poczuciu humoru, poszukiwaniu wsparcia instrumentalnego i zajmowaniu się czymś innym. Wykazano, iż pielęgniarki $\mathrm{z}$ najmłodszej kategorii wiekowej i z najkrótszym stażem pracy znacznie częściej wybierały strategie: pozytywne przewartościowanie, poczucie humoru oraz zajmowanie się czymś innym. Natomiast jako strategię radzenia sobie ze stresem $\mathrm{w}$ postaci poszukiwania wsparcia instrumentalnego częściej wybierały pielęgniarki $w$ grupie $36-45$ lat.

$\mathrm{Z}$ badań wynika również, iż wykształcenie pielęgniarek/pielęgniarzy miało wpływ na stosowanie strategii: poczucia humoru i zajmowania się czymś innym. Pielęgniarki które uzyskały tytuł magistra częściej stosowały strategię poczucia humoru. $\mathrm{Z}$ kolei jako strategię radzenia sobie ze stresem w postaci zajmowania się czymś innym częściej wybierały pielęgniarki posiadające tytuł licencjata pielęgniarstwa.

Czynniki te mają ogromne znaczenie dla praktyki pielęgniarskiej, gdyż pokazują, w którą stronę należy się udać, aby była ona jak najmniej stresogenna. W jaki sposób należy postępować, żeby nie doprowadzić do zaburzeń fizycznych i psychicznych ze strony organizmu. Jakich metod używać w praktyce pielęgniarskiej, aby móc wykonywać swój zawód w sposób sumienny, uczciwy, rzetelny, odpowiedzialny i empatyczny, zarówno w stosunku do pacjentów, jak i do współpracowników.

\section{Bibliografia / Bibliography:}

1. Borys B., Majkowicz M.: Psychologia w medycynie. Wyd. AMG, Gdańsk 2006;67-108,160-196.

2. Bartczak M.: Natężenie stresu i sposoby radzenia sobie ze stresem u ratowników medycznych i studentów ratownictwa medycznego. Rocznik Naukowy Kujawsko-Pomorskiej Szkoły Wyższej w Bydgoszczy 2010; 7-17. 
3. Basińska B., Wilczek Rużyczka E.: Zespół wypalenia zawodowego i zmęczenie w kontekście pracy zmianowej i stresu zawodowego wśród pielęgniarek chirurgicznych. Przegląd Psychologiczny 2011: 99-113.

4. Kędra E, Sanak K.: Stres i wypalenie zawodowe w pracy pielęgniarek. Piel. Zdr. Publ. 2013; 3 (2): 119-132.

5. Nowak - Starz G., Kozak B., Zdziebło K.: Wpływ stresu związanego z pracą zawodową na występowanie zespołu wypalenia zawodowego u pielęgniarek pracujących w oddziałach zabiegowych i zachowawczych. Studia Medyczne 2013; 29(1): 15-21.

6. Walden- Gałuszko K.: Psychoonkologia w praktyce klinicznej. Wyd. LekarskiePZWL, Warszawa 2014; 179-185.

7. Waszkowska M., Potocka A., Wojtaszczyk P.: Miejsce pracy na miarę oczekiwań - poradnik dla pracowników socjalnych. Wyd. Instytut Medycyny Pracy, Łódź 2010; 9-43.

8. Basińska M.A., Kasprzak A.: Związek między strategiami radzenia sobie ze stresem a akceptacją choroby w grupie osób chorych na łuszczycę. Przegląd Dermatologiczny 2012;6: 692-700.

9. Stres w miejscu pracy- stan prawny, przeciwdziałanie oraz działania związków zawodowych.

http://www.opzz.org.pl/documents/707532/707723/publikacja+stres. pdf [dostęp: 08.06.2018].

10. Sygit- Kowalkowska E.: Radzenie sobie ze stresem jako zachowanie zdrowotne człowieka- perspektywa psychologiczna. Hygeia Public Health 2014; 49(2): 202-208.

11. Ogińska- Bulik N., Juczyński Z.: Osobowość stres a zdrowie. Wyd. Difin, Warszawa 2010; 45-105,195-204,260-262. 
12. Andruszkiewicz A., Basińska B.: Strategie radzenia sobie ze stresem zawodowym przez pielęgniarki a ich zachowania i przeżycia związane z pracą. Polskie Forum Psychologiczne 2010;15; 2: 169-192.

13. Kowalczuk K, Zdańska A, Krajewska-Kułak E, Łukaszuk C, Van DammeOstapowicz K, Klimaszewska K, Kondzior D, Kowalewska B, Rozwadowska E.: Stres w pracy pielęgniarek jako czynnik ryzyka wypalenia zawodowego. Problemy Pielęgniarstwa 2011; 19 (3): 307314.

14. Modzelewska T, Kulik T.B.: Stres zawodowy jako nieodłączny element zawodów profesjonalnego pomagania - sposoby radzenia sobie ze stresem w opinii pielęgniarek. Annales Universitatis Maria SkłodowskaCurie, Lublin — Polonia, 2000; LVIII, supl. VIII, 161 sectio D: 312-316.

15. Pietraszek A, Charzyńska-Gula M, Łuczyk M, Szadowska-Szlachetka Z, Kachaniuk H, Kwiatkowska J.: Analiza przyczyn stresu zawodowego w opinii pielęgniarek. Journal of Education, Health and Sport. 2016; 6 (9): 643-652.

16. Tartas M., Derewicz G., Walkiewicz M., Budziński W.: Źródła stresu zawodowego w pracy pielęgniarek zatrudnionych w oddziałach o dużym obciążeniu fizycznym i psychicznym - hospicjum oraz chirurgii ogólnej. Ann. Acad. Med. Gedan., Gdańsk 2009; 145-153.

17. Śniegocka M., Śniegocki M.,: Analiza sposobów odpowiedzi na stres zawodowy wśród pielęgniarek. Problemy Pielęgniarstwa 2014;22 (4): 503-510.

Otrzymano: 10.01.2019r.

Zaakceptowano: 21.02.2019r. 